
ru)

\title{
ИСТОРИЧЕСКАЯ ПАМЯТЬ: РОЛЬ ГОСУДАРСТВА В ЕЕ ФОРМИРОВАНИИ
}

\begin{abstract}
Аннотация. Автор исходит из того, что историческая память народа выступает как фактор, формирующий и определяющий его облик, как его духовная скрепа. Сама историческая память - социальный конструкт. Это духовное образование формируется сознательной систематической и целенаправленной деятельностью различных социальных институтов. Их активность в этом направлении принято называть исторической политикой. Главным и самым влиятельным субъектом формирования и поддержания исторической памяти выступает государство. Его историческая политика анализируется в трех ракурсах: какой она должна быть, какой может быть, какой является.

Ключевые слова: историческая память, историческая политика, государство, «непредсказуемое прошлое», историческое образование
\end{abstract}

Л юбой народ свою самость и право на существование обосновывает историей: мы-де появились в мире не недавно, и такими, как есть, нас сделала история. Его историческая память выступает как фактор, формирующий и определяющий облик народа, как его духовная скрепа, она питает его исторический оптимизм.

Но она не априорна и не трансцендентна. Это духовное образование - социальный конструкт, и как таковой она формируется двояким образом.

С одной стороны, она спонтанно и стихийно создается живыми людьми, которые являются ее носителями и хранителями, и складывается в сознании народа в виде исторических преданий, сказаний, легенд, сказок, а также традиций, обычаев, поведенческих стереотипов. С другой стороны, историческая память формируется сознательной систематической и целенаправленной деятельностью социальных институтов (государство, структуры гражданского общества, церковь и объединения иных религий, литература и искусство и др.). Их активность в этом направлении создает феномен, получивший название «политика памяти», или «историческая политика». Главным и самым влиятельным субъектом формирования и поддержания социальной памяти выступает государство.

Во-первых, оно обладает мощными рычагами как ее конструирования, так и контроля над ней. Это общеобразовательная школа, исторические музеи, архивы и библиотеки, государственная символика, государственные каналы пропаганды (телевидение, кинопродукция и пр.), издательства, мемориалы и памятники, награды и почетные наименования (например, Город воинской славы, станция метро «Партизанская», Семеновский полк и др.), исторические объекты культурного наследия, топонимы, законодательно установленные государственные праздники, памятные даты и дни воинской славы.

Во-вторых, ее адресатами (потребителями) выступают предельно широкие массы. Так, всероссийский исторический «Диктант Победы», посвященный 75-летию Великой Победы, прошел в 85 регионах РФ и в 23 иностранных государствах. В нем приняли участие 105819 чел., из них 102792 - в РФ и 3027 - за рубежом ${ }^{1}$.

В-третьих, перефразируя известную максиму, можно сказать, что идеи и мне-

1 Диктант Победы. Доступ: https://xn--80achcepozjj4ac6j.xn--p1ai/ (проверено 18.11.2020). 
ния доминирующей в обществе силы являются доминирующими. Государство же по определению является доминирующей в обществе организацией.

Между тем в нашем обществе есть люди, отрицающие право и обязанность государства проводить историческую политику. Например, Н. Сванидзе, будучи членом президентской комиссии по противодействию попыткам фальсификации истории в ущерб интересам России, заявил: «Главная угроза для нас - если своим детям об истории мы будем рассказывать, объясняя те или иные события по указке государства».

Категорически не соглашаясь с этим, возражу словами В.В. Путина: «Государство обязано и имеет право и свои усилия, и свои ресурсы направлять... на формирование мировоззрения, скрепляющего нацию» .

Продвигая историческую политику, государство ответственно за организацию и ведение академических исследований истории и исторического образования в стране; историческую работу в органах государственной власти; создание государственных и государственно-общественных организаций, клубов исторической направленности; внедрение полученных результатов в теорию и практику государственного строительства, воспитания граждан России; активизацию интереса к изучению истории России и научно-просветительскую работу; формирование достойного отношения к истории России, чувства гордости за исторические и современные достижения страны; поддержку (в т.Ч. системой грантов, премий и т.п.) общественных движений поисковиков, реконструкторов истории, а также обращения к исторической тематике людей творческих профессий (кино, театр, литература); расширение сети и совершенствование работы музеев и архивов; установление государственного контроля за состоянием памятников истории и культуры; разоблачение фальсификаций истории и др.

В содержательном плане роль исторической политики государства следует анализировать в трех ракурсах: какой она должна быть, какой может быть и какой является.

Во-первых, она должна разрабатывать и культивировать историческую память положительной и победоносной коннотации. Принцип позитивной истории предполагает, что изучение и пропаганда знания о прошлом страны должны служить укреплению оснований для гордости за страну и ее историю, воспитанию национальной уверенности в силах и возможностях страны, здорового гражданского патриотизма. При этом негативные моменты истории (несправедливости, что творились по отношению к России и виновником которых была Россия) не оправдываются и не замалчиваются. Но отношение к ним должно соответствовать поговорке: «Кто старое помянет, тому глаз вон, а кто забудет - тому оба».

Во-вторых, историческая политика варьирует в широком диапазоне - от монополизации права на интерпретацию прошлого до отказа от какого бы то ни было участия в нем. Так, в свое время ложное представление об истории России формировал выпущенный под редакцией И.В. Сталина «Краткий курс истории ВКП(б)». Примером не безразличия даже, а фактического запрета «иметь историю» может служить статья 1972 г. «Против антиисторизма» руководителя отдела пропаганды ЦК КПСС А.Н. Яковлева, который утверждал, что антиисторично и, следовательно, вредно обращаться к истории своей страны и народа 2 .

\footnotetext{
1 Владимир Путин. Россия: национальный вопрос. - Независимая газета. Доступ: http:// www.ng.ru/politics/2012-01-23/1_national.html (проверено 18.11.2020).

2 Яковлев А.Н. Против антиисторизма. - Литературная газета. 1972. № 46.
} 
В-третьих, говоря о том, какой современная историческая политика российского государства является, следует признать, что, к сожалению, она непоследовательна. Несколько примеров в подтверждение.

1. Создание и упразднение Комиссии при Президенте по противодействию фальсификации истории в ущерб интересам России. Теперь в «Единой России» считают необходимым восстановить и обновить работу этой комиссии ${ }^{1}$. Мемориальная доска Маннергейму, установку которой «освятили» руководитель администрации президента и министр культуры; вскоре из-за протестов населения ее демонтировало Российское военно-историческое общество.

2. Разоблачение инсинуаций альтернативной (ревизионистской) истории. Но эта работа носит оборонительный, оправдательный характер.

Не стану говорить, подобно И. Шишкину, о провале исторической политики России, но нельзя не признать проблемы государственной исторической политики в современной России, о которой часто вслед за М. Задорновым говорят: «Великая страна с непредсказуемым прошлым». Здесь можно выделить:

- отсутствие концептуального обоснования современной модели государственной исторической политики;

- господствующую парадигму деполитизации и деидеологизации истории;

- $\quad$ слабость инфраструктуры и механизмов проведения эффективной исторической политики, площадок для общественно значимого диалога;

- отсутствие эффективной межведомственной взаимосвязи в процессах реализации исторической политики, единого государственного центра, для которого эти вопросы были бы предметом деятельности и сферой прямой ответственности;

- разнобой в школьном историческом образовании;

- тенденциозное использование истории оппозиционными политическими силами, «стеснительность» в противодействии ревизионистским концепциям истории.

Статья публикуется при поддержке Школы молодого этнополитолога в Республике Башкортостан (грант Фонда президентских грантов 19-2-022447).

\title{
HISTORICAL MEMORY: THE ROLE OF THE STATE IN ITS FORMATION
}

\begin{abstract}
The author proceeds from the fact that the historical memory of the people performs as a factor that shapes and determines its appearance, as its spiritual bond. Historical memory itself is a social construct. This spiritual construct is formed by the conscious systematic and purposeful activity of various social institutions. Their activity in this direction is called historical politics. The main and most influential subject of the formation and maintenance of historical memory is the state itself. Its historical policy is analyzed in three ways: what it should be, what it can be, what it is.
\end{abstract}

Keywords: historical memory, historical politics, state, "unpredictable past", historical education

\footnotetext{
1 Партия рекомендует восстановить Комиссию по противодействию попыткам фальсификации истории. - Официальный сайт партии «Единая Россия». Доступ: https://er.ru/ news/183770/ (проверено 18.11.2020).
} 